\title{
ILLEGAL INTERNET PHARMACIES AS A THREAT TO PUBLIC HEALTH IN EUROPE
}

DOI: 10.36740/WLek202109125

\author{
Nataliya 0. Gutorova', Vitalii M. Pashkov', Oleksii S. Soloviov² \\ 'POLTAVA LAW INSTITUTE OF THE YAROSLAV MUDRYI NATIONAL LAW UNIVERSITY, POLTAVA, UKRAINE \\ ${ }^{2}$ NATIONAL SECURITY AND DEFENSE COUNCIL OF UKRAINE, KYIV, UKRAINE
}

\begin{abstract}
The aim: This article aims to raise awareness and stimulate serious discussion about the dangers of illegal Internet pharmacies for patient safety and public health, the necessity to improve legal instruments, and unite the efforts of governments, professional organizations, and civil society for combating this activity.

Materials and methods: This study is based on the Medicrime Convention, empirical and analytical data of the WHO, Interpol, Europol, NABF, Directive 2011/62/EU of the European Parliament and of the Council of June 8, 2011, the regulatory acts and juridical practice of Ukraine, experts interview of pharmacy practicians, analysis of websites. Totally 18 laws and papers, 34 court judgments, 50 websites were analyzed, six experts were interviewed. Dialectical, comparative, analytic, synthetic, system analyses and sociological research methods were used.

Results: Illegal Internet pharmacies are widespread in Europe, especially during the COVID-19 pandemic. This black market poses a severe threat to patient safety and public health as falsifying, substandard, and smuggled medicines are sold through these channels. Without any exception, all illegal pharmacies sell prescription drugs without any prescriptions. Regulatory and protective legal instruments at the national and international levels are insufficient to counter the Internet trade in medicines.

Conclusions: The widespread proliferation of illegal Internet pharmacies in Europe requires European states to work together to protect patient safety and public health. A legal mechanism needs to be established to exchange information and combat illegal pharmaceutical activities on the Internet at the international level. At the national level, it is necessary to strengthen control over the wholesale of prescription medications to prevent them from entering the black market.
\end{abstract}

KEY WORDS: illegal Internet pharmacy, falsification of medicines, counterfeit medical products, public health, criminal liability, Medicrime Convention

Wiad Lek. 2021;74(9 p.l):2169-2174

\section{INTRODUCTION}

In the modern world, the use of medicines is a prerequisite for adequate medical care. Scientific advances in the development of new drugs have made it possible to significantly improve the quality and increase the life expectancy of people. At the same time, pharmaceutical activity belongs to the most profitable types of business, attracting the attention of unscrupulous players and organized criminal groups. Since the 90s of the last century, electronic trade in medicines has been actively developing globally. In contrast to the traditional sale of drugs through inpatient pharmacies, online pharmacies are much more difficult to control. Such pharmacies have begun to be used to distribute falsify, substandard, low-quality, and smuggled drugs. A significant part of prescription medicines, and in some cases containing narcotic and psychotropic substances, are sold online without prescriptions, posing a threat of negative consequences of self-medication and substance abuse. This criminal activity became especially widespread during the COVID-19 pandemic since, due to quarantine restrictions and fear of infection, consumers began to prefer buying goods over the Internet.

It should be noted that the legal regulation of online medicine trade in the EU and non-EU countries of Europe is significantly different. Countries outside the EU, such as Ukraine, often have very liberal legislation, which does not contain strict restrictions on the online sale of medicines, a mechanism for monitoring its implementation, and criminal punishment for illegal online trade. This situation poses a danger to public health in Europe since the delivery of medicines using a courier or post operator is not very difficult.

All this testifies to the relevance of issues of legal protection against illegal online drug trade by creating an effective mechanism at the national and regional European levels.

\section{THE AIM}

This article aims to raise awareness of and stimulate serious discussion about the dangers of illegal outline pharmacies for patient safety and public health, the necessity to improve legal instruments, and unite the efforts of governments, professional organizations, and civil society for combating this activity.

\section{MATERIALS AND METHODS}

This study was conducted in 2021 and based on the Medicrime Convention, Directive 2011/62/EU of the European 
Parliament and of the Council of June 8 2011, analytical reports of the WHO such as WHO Global Surveillance and Monitoring System (2017), A Study on the Public Health and Socioeconomic Impact of Substandard and Falsified Medical Products (2020), The WHO Member State Mechanism on Substandard and Falsified Medical Products (2020), report of Europol Viral Marketing Counterfeits, Substandard Goods and Intellectual Property Crime in the COVID-19 Pandemic (2020), empirical and analytical data of Interpol - Pharmaceutical Crime Operations, 2021, USA National Association of Boards of Pharmacy - Internet Drug Outlet Identification Program Progress Report for State and Federal Regulators, 2015, the national regulatory acts of Ukraine, verdicts of Ukrainian courts on the criminal liability of those who committed crimes in the field of pharmacy safety, experts interview of pharmacy practicians, analysis of websites. Totally 18 laws and papers, 34 court judgments, 50 websites were analyzed, six experts were interviewed.

Dialectical, comparative, analytic, synthetic, and system analyses sociological research methods were used.

\section{RESULTS}

\section{WIDESPREAD ILLEGAL ONLINE PHARMACIES DURING THE COVID-19 PANDEMIC}

Remote sale of medicines through Internet pharmacies has a higher risk of illegal activity than traditional pharmacies. Online pharmacies, which are used as channels to sell substandard and falsify medicines, pose the greatest danger.

The USA National Association of Boards of Pharmacy report (2015) informed that they have found $96 \%$ of nearly 11,000 websites selling prescription medicine online to be out of compliance with pharmacy laws and patient safety standards is further cause for concern [1].

Since 2008, Operation Pangea has been carried out annually worldwide, which the International Criminal Police Organization Interpol coordinates. This operation aims to combat the online trade of illegal medicines, involves law enforcement, customs, health authorities, and private sector representatives worldwide. Operation Pangea - XIV was carried out on May 18-25, 2021, in which 92 countries took part. Seven hundred ten thousand packages of medicines were checked, dangerous products in the amount of 23 million US dollars were seized, 113 thousand websites through which drugs were sold were shut down, 277 people were arrested [2]

A significant increase in illegal online sales of medical products during the COVID-19 pandemic is noted by the European Union's Law enforcement agency, Europol. According to the report Viral Marketing - Counterfeits, Substandard Goods and Intellectual Property Crime in the COVID-19 Pandemic (2020), the production and distribution closely followed the spread of COVID-19-related counterfeit pharmaceutical and healthcare products the COVID-19 pandemic to markets in the EU. The authors constated that these products rapidly appeared on the market in all Member States after the widening outbreak and the introduction of restrictive measures to contain the outbreak. The organized crime groups producing and distributing falsified goods have once again proven highly adaptable in shifting product focus, marketing, and packaging to suit or shape current demand. It was discovered that counterfeiters distributing falsify pharmaceutical products originating from Asia in the EU rely on complex illegal distribution chains to obscure the origin of the falsified medicines using several countries of the EU as well as Turkey and Ukraine as transit countries. According to Europol's Analysis Project on counterfeit goods, as of March 31, 2020 percentage of nationalities of suspects were mainly Poland (12,3\%), Romania (11,3\%), Ukraine (8,1\%). [3]

The concern of Europol that Ukraine is turning into a platform for comfortable and safe activities of organized groups involved in the illegal sale of drugs in the EU is justified. In Ukraine, distance selling of medicines has been allowed by law only since 2020, and since this period, there has been an active growth in the online medicine trade. Taking advantage of the lack of proper control by the state, illegal medicine traffickers use online pharmacies to sell falsify, illegally imported, and unregistered products. in Ukraine.

In May - July 2021, the article's authors conducted a pilot study of the illegal online pharmacy market in Ukraine, and the first results were published in August 2021 [4]. We chose the medicine subject to medical prescription "ALFLUTOP" produced by BIOTEHNOS S.A. (Romania) for the study. Biotechnos LLC (Ukraine) is the only legal distributor of this medicine in Ukraine, carrying out its import and wholesale. In Ukraine, "ALFLUTOP” (solution for injection, $1 \mathrm{ml}$ in vials, ten vials in a cardboard box) is registered based on the order of the Ministry of Health of Ukraine dated 11.10.2017 No. 1246 (2), registration permit number UA / 6889/01/01. Biotechnos LLC imported ALFLUTOP in yellow outer packaging at the time of the study, where the labeling and other information in Ukrainian are placed on a yellow background (Figure 1).

During the study, 50 websites were selected using the Google search engine that offered medicines for sale. Of the 50 websites, "ALFLUTOP" was offered for sale in Ukraine on 38 websites that positioned themselves as online pharmacies or medicine delivery services. Out of 38 sites, 22 offered for sale "ALFLUTOP," registered in Ukraine, in a yellow outer packaging with an inscription in Ukrainian (Fig. 1). Sixteen websites contained information with an offer to sell "ALFLUTOP" unregistered in Ukraine with inscriptions on the outer packaging in Russian in different dosages (Fig. 2 and Fig. 3), as well as in Romanian (Fig. 4).

Analysis of the information contained on these sites made it possible to divide them into two groups. The first group included websites that did not mention the legitimate nature of the activity (the so-called black market). Some of them even reported that they were offering a lower price since their activity on importing medicines into Ukraine and the trade of medicines was not controlled by the state; when buying several packages of one medicine (10 


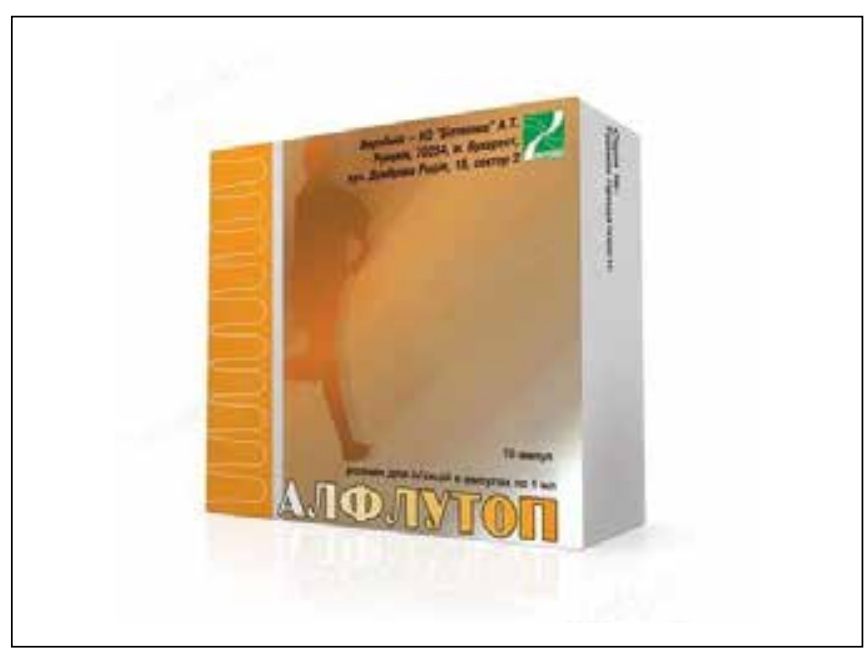

Fig. 1. The outer package registered in Ukraine "ALFLUTOP" (solution for injection, $1 \mathrm{ml}$ in vials, ten vials in a cardboard box) with inscription in Ukrainian.

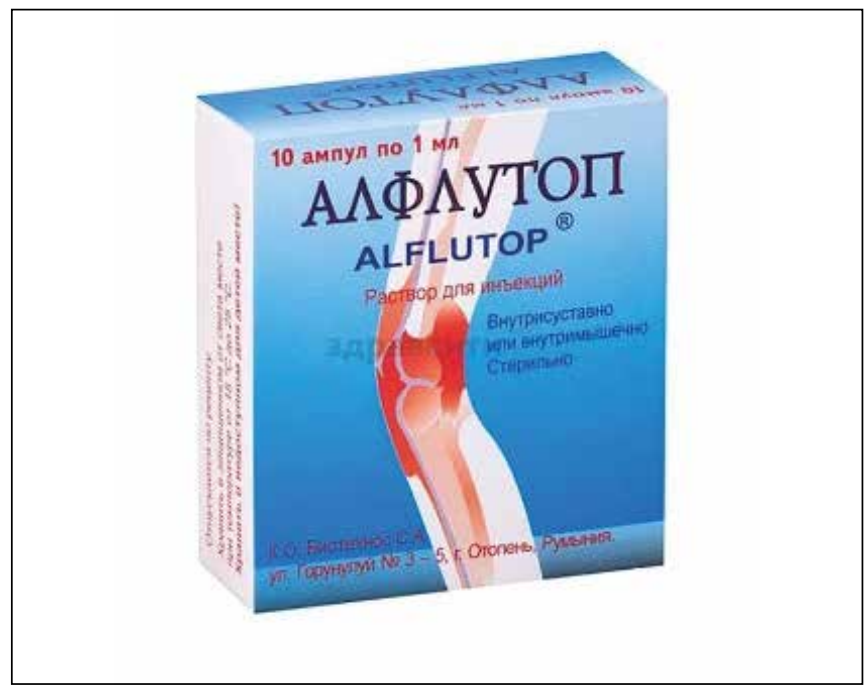

Fig. 3. The outer package unregistered in Ukraine "ALFLUTOP" (solution for injection, $1 \mathrm{ml}$ in vials, ten vials in a cardboard box) with inscription in Russian.

or more), they offered a discount. Typical of these black market sites was the lack of any location information or landline number. Communication with the buyers was carried out through the feedback system on the site or using a mobile phone. On the sites of the second group - (the so-called gray market) - there was an attempt to legitimize their activities, saying that they are the delivery service for medicines registered in Ukraine that they buy for consumers in legal pharmacies of Kyiv; it was also mentioned that prescription medications might require a prescription. These sites contained information about where the buyer could get the medicines himself, as well as a landline phone number. At the same time, personal communication through the proposed communication channels showed that a prescription for medications is not required, the medicines are already in the company's warehouse, and they will not buy them at the pharmacy. All these facts and the sale of the unregistered in Ukraine

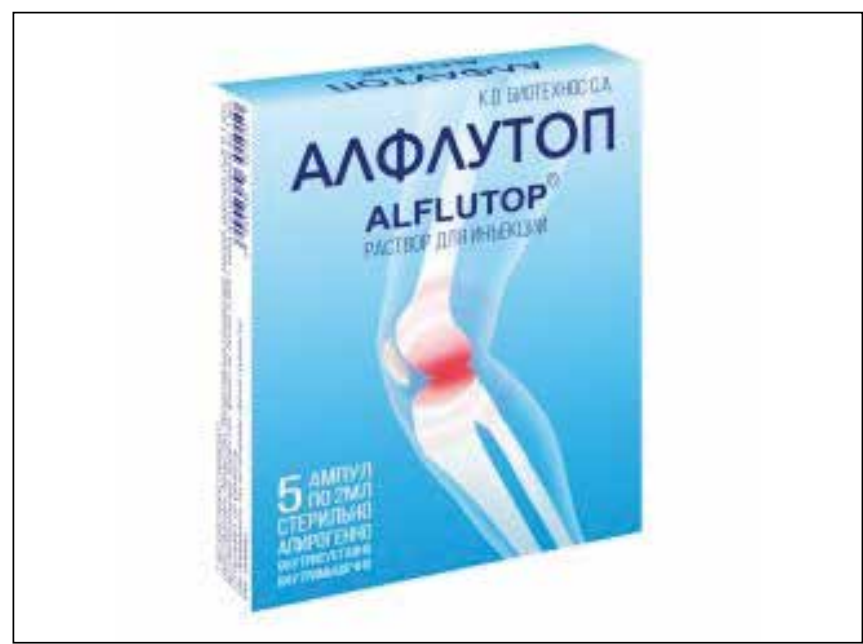

Fig. 2. The outer package unregistered in Ukraine "ALFLUTOP" (solution for injection, $2 \mathrm{ml}$ in vials, five vials in a cardboard box) with inscription in Russian.

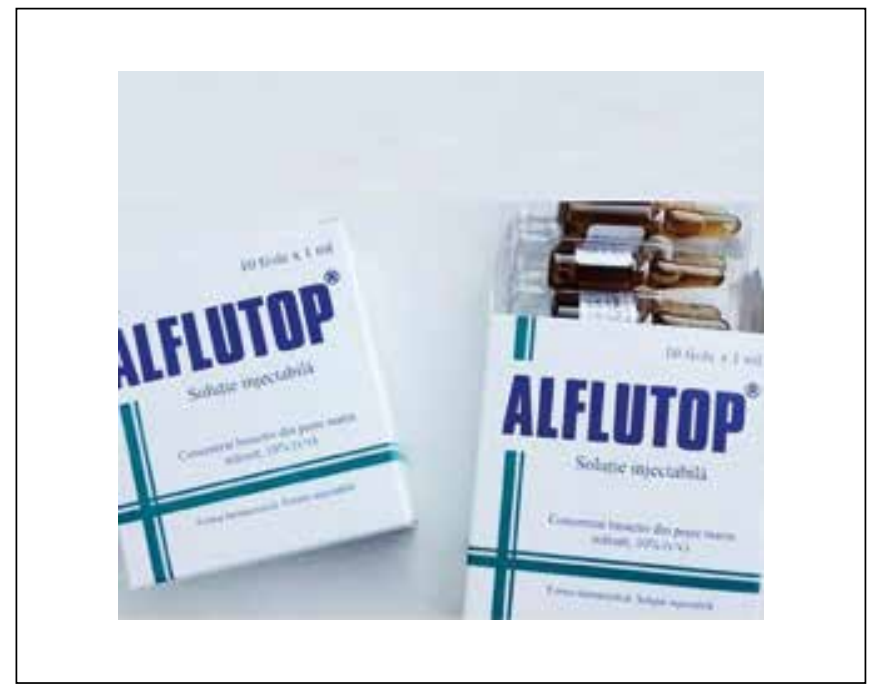

Fig. 4. The outer package unregistered in Ukraine "ALFLUTOP" (solution for injection, $1 \mathrm{ml}$ in vials, ten vials in a cardboard box) with inscription in Romanian.

"ALFLUTOP" testified that they, as representatives of the gray market, were engaged in the same types of illegal medicine sales as the representatives of the black market.

Most of the sites classified as both black and gray markets contained proposals for delivering medicines in Ukraine and any of the EU countries and the former Soviet Union. When sending outside Ukraine, prepayment was required.

Illegal online medicine dealers through black and gray market sites acted openly; if desired, law enforcement and regulatory agencies could quickly identify the person who sent or delivered medicines to the buyer and the recipient of payment for them.

A content analysis of the websites used in Ukraine for the online sale of medicines has shown that illegal trade in medicines, including unregistered medicines in Ukraine, is widespread and is carried out openly.

The lack of control over the origin and quality of medicines in Ukraine in the rapidly growing online market 
creates favorable conditions for the circulation of falsified medicines. At the same time, the analysis of judicial practice on the application of Art. $321^{1}$ of the Criminal Code of Ukraine, "Falsification of medicines or circulation of falsified medicines," indicates that out of 28 sentences of the courts of Ukraine passed under this article from 2013 to 2021, the only one says online sales of falsified medicines. So, by the verdict of the Shevchenko District Court in Kyiv, a person acting as part of an international organized criminal group was convicted of selling a falsified medicine "KEYTRUDA" using the Internet. [5]

\section{INTERNATIONAL INSTRUMENTS AGAIN ILLEGAL ONLINE TRADE OF MEDICINES}

26/06/2012, the Sixty-fifth World Health Assembly established WHO Member State mechanism on substandard/ spurious/falsely-labelled/falsified/counterfeit medical products. The goal of Member State mechanism is "to protect public health and promote access to affordable, safe, efficacious and quality medical products, promote, through effective collaboration among the Member States and the Secretariat, the prevention and control of substandard/spurious/falsely-labelled/falsified/counterfeit medical products and associated activities." [6] It coordinates efforts of Member States with individual countries taking the lead on activities where they were best able to contribute. [7]

One of the results of the WHO Member State mechanism's activity is the development of a unified terminology common to all Member States and other stakeholders, which allows both unifies and simplifies the description of the issue from a public health perspective [7] It has adopted the following definitions:

"substandard medical products - also called "out of specification," these are authorized medical products that fail to meet either their quality standards or their specifications, or both;

unregistered/unlicensed medical products - medical products that have not undergone evaluation and/or approval by the national or regional regulatory authority for the market in which they are marketed/distributed or used, subject to permitted conditions under national or regional regulation and legislation;

falsified medical products - medical products that deliberately/fraudulently misrepresent their identity, composition or source." [8].

An international legal instrument again illegal pharmacy activity is the Council of Europe Convention on the counterfeiting of medical products and similar crimes involving threats to public health - (The Medicrime Convention) (Moscow, 28/10/2011). This Convention is the first international criminal law instrument to oblige States Parties to criminalize the counterfeiting of medical products and similar crimes involving threats to public health. It provides a framework for national and international cooperation across the different sectors of the public administration, measures for coordination at the national level, preventive measures for use by the public and private sectors, and protection of victims and witnesses. [9] At the same time, as of August 15, only 35 countries have signed, and 18 ratified the Medicrime Convention. [9] However, it is not enough to create an effective international legal mechanism for combating these crimes.

It should be noted that there are contradictions in the terminology developed by WHO and used in the Medicrime Convention, as WHO uses the term "falsified medical products" to define the products that the Medicrime Convention designates as "counterfeiting of medical products." Such terminological contradictions and lack of harmonization also do not increase the effectiveness of international instruments against public health crimes.

A significant problem in the WHO Member State mechanism is the lack of legal instruments to exchange information and combat illegal trade in Substandard and Unregistered/unlicensed medical products. The absence of such a tool in the context of widespread illegal online medicine trade reduces the ability to fight criminal groups operating, as a rule, on the territory of several states. International organized crime has successfully exploited this situation to expand the illicit trade in medicines dangerous to public health. There is a need to create an international legal mechanism to combat the illicit medicine trade. For these purposes, the legal mechanism provided for by the Medicrime Convention can be used, which, subject to consensus, can also be extended to the illegal trade in Substandard and Unregistered/unlicensed medical products.

The EU has Directive 2001/83 / EC of the European Parliament and of the Council of November 6, 2001, on the Community code relating to medicinal products for human use [10], which requires member states to establish rules for the handling of medicines that must protect public health from products hazardous to the life and health of patients entering the market.

Additional measures in this direction were taken by the adoption of Directive 2011/62/EU of the European Parliament and of the Council of June 8, 2011, amending Directive 2001/83/EC on the Community code relating to medicinal products for human use, as regards the prevention of the entry into the legal supply chain of falsified medicinal products. [11] At the same time, as the study of the Ukrainian market shows, the established requirements are not always observed. According to article 85 a Directive 2001/83/EC "Where wholesale distributors supply medicinal products to persons in third countries, they shall ensure that such supplies are only made to persons who are authorized or entitled to receive medicinal products for wholesale distribution or supply to the public in accordance with the applicable legal and administrative provisions of the third country concerned." Despite this, many prescription medicines produced by the EU pharmaceutical company for consumption in one of the EU countries are smuggled into Ukraine on the Ukrainian illegal online market. One example is the widespread distribution of the Romanian prescription medicine "ALFLUTOP" in outer packaging in Romanian. There is every reason to assume that, despite the legal prohibition, a Romanian distributor 
(or distributors) sells this medical product to persons who do not have permission to import and trade in medicines in Ukraine. As a result, a favorable ground is created for the development of illegal online trade in medicines, which threatens to sell low-quality or falsify medicines.

The preceding indicates the need to strengthen control measures in the EU over the sale of medicines to third countries.

\section{UKRAINIAN NATIONAL INSTRUMENTS AGAIN ILLICIT ONLINE TRADE OF MEDICINES}

In Ukraine, distance retailing of medicines was first allowed by the Government in March 2020; this permit was temporary and applied only for the period of establishing a quarantine or declaring a state of emergency. On January 14,2021 , amendments to the Law "On Medicines" were introduced to implement electronic retail trade in medicines and established legal requirements for this trade. These legal requirements were broadly in line with the Directive $2011 / 62 / \mathrm{EU}$, and should have protected the market from the illegal online medicine trade. [12]

At the same time, it should be noted that Ukraine has not developed a mechanism for monitoring the implementation of the online medicine trade, and therefore the legislative restrictions are of a declarative nature and are not applied in practice. This situation negatively affects the online medicine market, creating conditions for the illegal sale of contraband, substandard and falsified medicines.

\section{EXPERT OPINIONS}

The interviews of six experts in the field of pharmacy conducted in the framework of this study showed that they are all concerned about the rapid growth of the black market for online drug sales in Ukraine and the lack of effective mechanisms to counter this phenomenon. Employees of the State Service of Ukraine on Medicines and Drugs Control focused on the fact that even if they become aware of such illegal activities, they do not have the authority to check business entities that do not have a license to trade in medicines. Contacting the National Police makes sense only in case of detection of illegal circulation of falsifying medicines since the current legislation of Ukraine does not provide for criminal liability for illegal pharmaceutical activities.

The heads of business entities licensed and engaged in the retail trade of medicines drew attention to the fact that recently they are increasingly being approached by patients with a request to explain how medicines in a pharmacy differ from those bought on the Internet. Moreover, they often report that they learned about the opportunity to buy medicines at a lower price from doctors who provided them with a phone number or links to the site.

The heads of business entities that have a license and are engaged in the import and wholesale of medicines expressed their indignation that the illegal Internet market in Ukraine is unimpeded, without observing any requirements for storage and payment of taxes. They repeatedly appealed to law enforcement agencies about such actions, but they were told there was no criminal responsibility for this activity since the medicines were not falsified.

\section{DISCUSSION}

The danger to public health of the illegal sale of medicines via the Internet and the need to create an effective legal mechanism to counter such activity is beyond doubt. Many authors study this issue, primarily in the aspect of combating the spread of falsified medical products. In particular, they consider the legal aspect of falsifying medicines and their trade in the EU countries [13], creating a criminal law mechanism to counter threats to public health due to such criminal activity [14]. The public health dangers of illegal online medicine sales are not limited to the spread of counterfeit products. Researchers point out that illegal Internet pharmacies sell all prescription medicines without a prescription, and the products of such pharmacies are often of poor quality [15]. Researches have provided evidence regarding the connection between infodemic and its consequences on the illicit online pharmacy market [16]. Given the increasing ease of access to online medication purchases, global and national health professional, societal, and patient-specific collaborations are necessary to affect the significant public health threat, especially during the COVID-19 Pandemic [17].

\section{CONCLUSIONS}

Illegal Internet pharmacies are widespread in Europe and pose a significant threat to patient safety and public health. This activity intensified significantly during the COVID-19 pandemic. Illegal Internet pharmacies sell falsify, smuggled, low-quality drugs; all prescription drugs are sold over the counter.

The widespread proliferation of illegal Internet pharmacies in Europe requires European states to work together to protect patient safety and public health, unite the efforts of governments, professional organizations, and civil society for combating this activity.

Although the legal regulation of pharmaceutical activities in the EU states contains severe restrictions, in fact, it does not protect from the sale of prescription medicines produced in the EU to illegal traders. This situation contributes to filling the illegal online market with products demanded by patients, which creates conditions for its expansion. In this regard, governments should control the selling of medicines to pharmaceutical companies and wholesalers to prevent illegal traders from entering the chain.

A legal mechanism needs to be established to exchange information and combat illicit pharmaceutical activities on the Internet at the international level. Consideration should be given to expanding the mechanism provided for by the Medicrime Convention for combating the illegal online medicine trade.

A content analysis of the websites used in Ukraine for the online sale of medicines has shown that illegal trade in 
medicines, including unregistered medicines in Ukraine, is widespread and is carried out openly. Illegal Internet pharmacies sell drugs in Ukraine and also send them to other European countries. The legal regulation of distance-selling medicines is insufficient; there is no state control over this activity. The illegal sale of medicines under the criminal law of Ukraine is not a crime, except for cases when falsified medicines are sold. This situation threatens Ukraine and other European countries' public health and requires immediate change by adopting appropriate legal regulation. It is necessary to strengthen control over the wholesale of prescription medications to prevent them from entering the black market and criminalize medicine smuggling and illegal pharmaceutical activities, regardless of the harm to the patient's health.

\section{REFERENCES}

1. Internet Drug Outlet Identification Program Progress Report for State and Federal Regulators: April 2015. National Association of Boards of Pharmacy. https://nabp.pharmacy/wp-content/uploads/2016/08/ NABPIDOIReport_April2015.pdf

2. Pharmaceutical Crime Operations. Interpol. URL: https://www.interpol. int/en/Crimes/llicit-goods/Pharmaceutical-crime-operations

3. Viral marketing Counterfeits, substandard goods and intellectual property crime in the COVID-19 pandemic. Europol, April 172020. URL: https://www.europol.europa.eu/publications-documents/viralmarketing-counterfeits-substandard-goods-and-intellectual-propertycrime-in-covid-19-pandemic

4. Gutorova N.0. Chornyi onlain rynok likarskykh zasobiv pid chas pandemii COVID-19: pravovizasoby protydii [Legal Remedies against Black Online Market of Medicines during COVID-19 Pandemic]. Forum Prava. 2021; 68(3). http://doi.org/10.5281/zenodo.5075677 (In Ukrainian)

5. Yedynyi derzhavnyi reiestr sudovykh rishen. Vyrok Shevchenkivskoho raionnoho sudu m. Kyieva vid 15 zhovtnia 2020 roku [The verdict of the Shevchenko district court of Kyiv from 0ctober 15, 2020]. https:// reyestr.court.gov.ua/Review/92843132\#

6. WHA65.19 Substandard/spurious/falsely-labelled/falsified/counterfeit medical products. https://www.who.int/medicines/regulation/ssffc/ mechanism/WHA65.19_English.pdf

7. The WHO Member State Mechanism on Substandard and Falsified Medical Products. June 24 2020. URL: https://www.who.int/ publications/i/item/WHO-MVP-EMP-SAV-2019.04

8. Seventieth World Health Assembly, March 20 2017. Member State mechanism on substandard/spurious/falsely-labelled/falsified/counterfeit medical products Report by the Director-General. Appendix 3. URL: https:// apps.who.int/gb/ebwha/pdf_files/WHA70/A70_23-en.pdf

9. Council of Europe Convention CETS No. 211 on the counterfeiting of medical products and similar crimes involving threats to public health. Moscow, dated 28.10.2011. https://www.coe.int/en/web/conventions/ full-list/-/conventions/treaty/211

10. Directive 2001/83/EC of the European Parliament and of the Council of November 62001 on the Community code relating to medicinal products for human use. URL: https://eur-lex.europa.eu/legal-content/ EN/TXT/?uri=CELEX\%3A02001L0083-20190726
11. Directive 2011/62/EU of the European Parliament and of the Council of June 82011 amending Directive 2001/83/EC on the Community code relating to medicinal products for human use, as regards the prevention of the entry into the legal supply chain of falsified medicinal products. https://eur-lex.europa.eu/legal-content/EN/ TXT/?uri=celex\%3A32011L0062

12. Pro vnesennya zmin do statti 19Zakonu Ukrayiny "Pro likars'ki zasoby" shhodo zdijsnennya elektronnoyi rozdribnoyi torgivli likars'ky'my” zasobamy `». Zakon Ukrayiny’ vid 17 veresnya 2020 roku № $904-$ IX. [Law of Ukraine from 17.09.2929 № 904-IX“ “n amendments to Article 19 of the Law "On Medicines" in terms of the implementation of electronic retail trade-in medicines"]. (In Ukrainian) URL: https://zakon.rada.gov. ua/laws/show/904-20\#Text

13. Pashkov V, Soloviov A, Olefir A. Legal aspects of counteracting the trafficking of falsified medicines in the european union. Wild Lek. 2017;70(4):843-849.

14. Gutorova N, Zhytnyi 0, Soloviov 0. Falsification of medical products: criminal law mechanism combating threats to public health. Wiad Lek. 2019;72(5 cz 1):856-861.

15. Mackey TK, Nayyar G. Digital danger: a review of the global public health, patient safety and cybersecurity threats posed by illicit online pharmacies. Br Med Bull. 2016;118(1):110-126. doi:10.1093/bmb/dw016

16. Fittler A, Adeniye L, Katz Z, Bella R. Effect of Infodemic Regarding the Illegal Sale of Medications on the Internet: Evaluation of Demand and Online Availability of Ivermectin during the COVID-19 Pandemic. Int J Environ Res Public Health. 2021;18(14):7475. Published 2021 July 13. doi:10.3390/ijerph18147475

17. Fincham JE. Negative Consequences of the Widespread and Inappropriate Easy Access to Purchasing Prescription Medications on the Internet. Am Health Drug Benefits. 2021;14(1):22-28.

\section{ORCID and contributionship:}

Nataliya O. Gutorova: 0000-0003-2485-0651 A,B,D,E,F

Vitalii M. Pashkov: 0000-0001-9489-7768 ${ }^{A, B, D, E}$

Oleksii S. Soloviov: 0000-0002-6615-4868 A,B,D,F

\section{Conflict of interest:}

The Authors declare no conflict of interest

\section{CORRESPONDING AUTHOR Nataliya 0. Gutorova}

Poltava Law Institute of Yaroslav Mudriy

National Law University, Poltava, Ukraine

e-mail: natalygutorova@gmail.com

Received: 29.06 .2021

Accepted: 25.08 .2021

A - Work concept and design, B - Data collection and analysis, C - Responsibility for statistical analysis,

D-Writing the article, $\mathbf{E}$-Critical review, $\mathbf{F}$ - Final approval of the article 